\title{
Víctor Infantes (1950-2016), marca de agua
}

\author{
Pedro Ruiz Pérez \\ Universidad de Córdoba
}

Hace unos días llegaba el último aguinaldo navideño de Víctor Infantes. El número 20 de una preciosa serie, convertida ya en gozosa costumbre y ansiado regalo en estas fechas. En un sobre ad hoc y con una inconfundible caligrafía, llegaba siempre una sorpresa, algo diferente al año anterior, pero siempre con dos rasgos constantes: una mirada única sobre el libro y la literatura y una generosidad sin límites.

El aguinaldo número 20 nos regalaba algo más que una curiosidad. La reproducción de la portada de un ejemplar de la Segunda parte del Quijote de la imprenta de Juan de la Cuesta (1615), con la firma de Cervantes y la indicación de dónde guardaba el libro, viene acompañada de una nota con las reconocibles características en los textos del autor: brevedad, condensada erudición, gusto por la expresión ingeniosa y, sobre todo, una nueva luz sobre los hechos literarios y sus posibilidades de estudio. En este caso, se trataba de algo más que una efeméride (de las que se multiplicaban en la prodigiosa memoria de Infantes): la materia y la firma conjunta con Ana Martínez Pereira remitían a dos enjundiosos proyectos de investigación, desarrollados en los últimos seis años, que han puesto sobre la mesa de los filólogos nada más y nada menos que un censo de los ejemplares conservados de las tiradas iniciales de las dos partes del Quijote. De nuevo encontramos una síntesis, esta vez a lo grande, de una manera de hacer marcada por la delimitación de un objeto preciso, su estudio sistemático y el resultado de una visión siempre nueva sobre las facetas más diversas de las prácticas literarias. Así quedan atendidos los procesos de composición de los textos, de su reproducción y transmisión, de su codificación y lectura, pero también de su conservación y del aura 
que un transcurso de siglos ha añadido a su perfil. En su método aplicaba el rigor y el calor de la filología más viva, y este saber lo fusionaba con su otra pasión, la bibliografía, convertida en sus manos en algo más (que también) una mera nómina de impresos. A la zaga de admirados maestros, como Rodríguez Moñino, Infantes logró de manera inigualable aunar ambas tradiciones para revivificarlas y, sobre todo, otorgar nueva vida a los textos, incluso los más olvidados o periféricos.

Así operó desde las Danzas de la muerte a la poesía experimental del siglo XX, con una especial predilección por los periodos medieval y áureo. No se alejó de las grandes obras de estos períodos, y, junto al Quijote, ahí están sus trabajos sobre La Celestina para demostrarlo. Sin embargo, como en sus aguinaldos, Infantes siguió con preferencia los caminos menos usados, las vías menos atendidas en la lectura y la investigación. Y ello atañe tanto a los objetos de estudio (y de amor por el libro) como a los enfoques críticos. Entre los primeros, recuperó para nuestra consideración, entre otras joyas olvidadas, los pliegos poéticos, la literatura del erotismo, las historias caballerescas breves o los juegos visuales del ingenio poético barroco, en cuidadas ediciones y atentos estudios. De sus reflexiones surgieron para quedarse en nuestro acervo conceptual nociones como las de "género editorial" o reflexiones sobre las formas de titulación en los textos tardomedievales, el papel de las cartillas para aprender a leer y los modos de abordar el estudio de las bibliotecas a partir de los documentos, por no agotar los ejemplos. Algunas de las principales líneas de estudio en nuestro campo serían impensables, por no decir imposibles, sin los trabajos y la figura de Víctor Infantes. Y, lo que es más importante, como sus alumnos en el aula, a quienes escuchamos sus intervenciones en una reunión científica, nos será difícil olvidar el doble efecto que nos causaba, primero de pasmo, luego de estímulo, siempre de agradecimiento por el saber que regalaba con una elegancia que apoyaba en el guiño irónico, con un saber que camuflaba bajo el aparente chiste, con una generosidad que diluía en afabilidad.

Su lección es inimitable, pero debemos seguirla en lo que esté a nuestro alcance, y ello nos lleva de nuevo al aguinaldo. En este mundo de lo virtual, Infantes se acogía a la realidad de la materia, en su caso, en nuestro caso, el impreso, y nos recordaba que en la tipografía manual la imagen iba sustancialmente unida a la palabra, en ilustraciones, composiciones, 
variantes tipográficas, experimentos compositivos... Toda una visualidad presente siempre en su consideración, en sus estudios y en muchos de sus trabajos. Al reproducir una portada, un taco xilográfico, una anotación marginal o el fragmento de un cartel poético, Infantes dejaba atrás la tarea del arqueólogo, pero también la del especulador, pues ni le tentaba la especulación de un mercado de piezas únicas y escondidas, ni la elucubración sin riendas al margen de la realidad de los textos. El placer era el de compartir, el de recordar la existencia de pequeńos tesoros y facilitar su disfrute, el deseo de ampliar la extensión de nuestra mirada desde las cimas más altas al detalle más nimio, e igualmente significativo. El regalo navideño, con la constancia de dos décadas, lo encerraba todo en un minúsculo trozo de papel, cuidado hasta el extremo, siguiendo las reglas que la tradición tipográfica reservaba para sus iniciados. E Infantes lo era. El colofón siempre daba precisa cuenta de ello, al tiempo que de las circunstancias, materiales y soportes de la composición, en la que las manos que firmaban tenían también mucho que ver con la elaboración material de esta pequeña joyita bibliográfica.

No siempre pequeñas, ni siempre ceñidas al ámbito bibliográfico, las obras de Víctor Infantes sí eran siempre una joya. Como las verdaderas, sin precio, porque las regalaba, ya fuesen de palabra o en el papel. El filológico y el bibliográfico no fueron los únicos saberes en su figura. Como ellos, dominó dos no menos importantes: el del magisterio y el de la amistad. Como en aquellos, supo abatir las fronteras entre uno y otra. Es lo que hacía que su verbo calara de una manera especial y que su cordialidad envolviera la almendra del saber. Sólo una convención nos hace hablar de él y de su obra en pasado. Aunque sus aguinaldos no vuelvan en los próximos años, su figura, su palabra y su enseñanza estarán siempre con nosotros, como una marca de agua en los papeles que tanto amó. 